\title{
The Impact of the COVID-19 Pandemic on Socio- Economic Development: a Case Study of Tourism Services, Textile and Garment industry in Vietnam
}

\author{
Binh Dao Thanh ${ }^{1, *}$ Barysheva G.A. ${ }^{2}$ Ngoc Tran Thi Bich ${ }^{1}$
}

\author{
${ }^{1}$ Hanoi University of Science and Technology, Dai Co Viet, Hanoi, Viet Nam \\ ${ }^{2}$ Tomsk Polytechnic University, Tomsk, Russia \\ *Corresponding author. Email: binh.daothanh@hust.edu.vn
}

\begin{abstract}
The article provides an overview and analysis of the unprecedented impacts of the COVID-19 pandemic outbreak on Vietnam's economy at the current time; examines the need to reshape supply chains (SCs) and markets in the context of the unpredictable fluctuations of a changing world and the long-lasting pandemic effects. The Vietnamese government's response is described as overall financial measures to help businesses and people stabilize their lives and maintain production. Methods of data synthesis and analysis is applied to clarify the status and dependence of Vietnamese industries and services on global markets in the globalization process, using empirical case study of tourism services and Vietnam's textiles and garments industry (VTGI), which are two key sectors of the Vietnam's economy. The individual views expressed by the authors during the discussion can be helpful for making appropriate policies and decisions.
\end{abstract}

Keywords: COVID-19 pandemic, supply chain, sourcing overseas, foreign supplier, import dependence, import substitution

\section{INTRODUCTION}

Current COVID-19 pandemic outbreak transmitted worldwide has the severe impact on public health and economic growth, causing unpredictable human and economic losses.

As of October 14, 2020, while in the world over 38 million coronavirus cases were recorded with 1 million deaths. In Vietnam, thanks to the government and community antiepidemic, the total number of COVID-19 cases was only 1,113 cases, of which 1026 were recovered; the number of deaths was 35 cases related to coronavirus-infected elderly with severe underlying disease [1]. Since the coronavirus outbreak, two waves of epidemic were witnessed in Vietnam:

- First wave from January to April; the total number of cases was 270; all recovered;

- Second wave from July 25 to September 2, 2020; outbreak was in Da Nang tourist city, there were 551 cases related to the Da Nang's outbreak.

The time gaps from May to the end of July and from the beginning of September up to October 13, 2020, there was no case registered in the community; the cases registered are Vietnamese and foreigners entered Vietnam.

Countries affected by Coronavirus pandemic have spent huge sums of money to prevent and control COVID -19 pandemic, rescue the economy, support businesses and citizens. Besides, in April 2020, the International Monetary Fund (IMF) published its forecast of economic losses caused by the COVID-19 pandemic in form of gross domestic product (GDP) growth variation (Table 1).

Table 1 IMF economic growth projections for 20202021, by region: Real GDP

\begin{tabular}{|l|c|c|c|}
\hline \multirow{2}{*}{$\begin{array}{l}\text { Region and } \\
\text { countries }\end{array}$} & 2019 & \multicolumn{3}{|c|}{ Real GDP } \\
\cline { 2 - 4 } & 2.0 & -6.0 & 2021 \\
\hline $\begin{array}{l}\text { North } \\
\text { America }\end{array}$ & 1.2 & -2.8 & 4.5 \\
\hline $\begin{array}{l}\text { Middle East } \\
\text { and Central } \\
\text { Asia }\end{array}$ & & & \\
\hline Europe & 1.6 & -6.6 & 4.5 \\
\hline $\begin{array}{l}\text { Emerging and } \\
\text { Developing }\end{array}$ & 2.1 & -5.2 & 4.2 \\
Europe & & & \\
\hline Asia & 4.6 & 0.0 & 7.6 \\
\hline \multicolumn{1}{|c|}{ ASEAN-5 } & 4.8 & -0.6 & 7.8 \\
\hline Indonesia & 5.0 & 0.5 & 8.2 \\
\hline Thailand & 2.4 & -6.7 & 6.1 \\
\hline Malaysia & 4.3 & -1.7 & 9.0 \\
\hline Philippines & 5.9 & 0.6 & 7.6 \\
\hline Vietnam & 7.0 & 2.7 & 7.0 \\
\hline
\end{tabular}

Source: IMF World Economic Outlook Report [2]

The impact of this pandemic on society life and the global economy is unpredictable. By the end of June 2020 the IMF has made another projection that the coronavirus pandemic has caused more widespread damage than 
expected. The global economy will shrink $4.9 \%$ this year, which is worse than the expected 3\% decline in April 2020. By the end of 2021, the pandemic will have cost the global economy US\$12.5 trillion in lost output [3].

The spread of the Covid-19 pandemic is being multiplied by free trade and widespread travel across continents. Today's economic globalization has amplified the crossborder impacts of the epidemic as it creates interdependence among economies in global supply chains (GSCs) for raw materials, components, equipment, consumer goods, and import-export. Social distancing practiced in countries and territories suffering from pandemic and temporary stoppage of suppliers, transporters or manufacturers can disrupt activities of others that lead to reducing demand, consumer purchasing ability, increasing unemployment, service systems collapsing, etc. This domino effect quickly spreads inside the country and from one country to another.

In essence, it can be understood that COVID-19 pandemic causes market and SC disruptions in all economic sectors on a global scale. The term "supply chains" was increasingly used with the corresponding SC management concept, presented by consultants in the 1980s when the issue related to the material line was first introduced [4]. Chopra and Meindl [5] believe that a SC consists of all parties involved, directly or indirectly, in fulfilling a customer request. I.V.Kozlenkova et al [6], studying the SCM concept in marketing channels, concluded that in commerce, SC is a system of organizations, people, activities, information, and resources involved in supplying a product or service to a consumer. It includes not only the manufacturer and suppliers, but also the domains of marketing channels, logistics, purchasing, downstream relationships, connecting the firms to the end customers.

In ASEAN, the uncertainties brought about by the pandemic also triggered a swift outflow of capital, causing a dive in the markets and a rapid depreciation of the exchange rates across the region. Around a fourth of the stock market values in Indonesia, Philippines, Thailand, and Vietnam were vaporized. The highest drop was in Vietnam, where the VN index fell by $29.3 \%$ from 936.6 at the end of January to 662.5 by the end of March. [7].

The article aims to provide an overview and analysis of the unprecedented impact of the COVID-19 pandemic outbreak on Vietnam's economy at the current time and to examine the need to reshape the SCs, input and output markets in context of possible changes under the impact of continuing COVID-19 pandemic.

\section{RESEARCH METHODOLOGY AND MATERIALS}

The desk research and integrated approach methodology were used in the study to examine the impact of the COVID-19 pandemic on the Vietnam's economy in general and SC and market disruption in particular, using data from published materials, IMF World Economic
Outlook and Vietnam Chamber of Commerce and Industry (VCCI) Survey results. The methods of data collection and data analysis were also applied to determine the import dependence in the manufacturing and processing sectors, and evaluate the impact of SC disruption caused by Covid19 pandemic on Vietnam's enterprises. Officially published secondary data was collected from Vietnamese sources such as General Statistics Office (GSO) of Vietnam, General Department of Vietnam Customs, Vietnam Textile and Apparel Association (VITAS), related studies of Vietnamese and foreign researchers were used in the study in the form of citations, figures and tables to clarify research results.

Comparative method is also applied to determine the difference between GDP growth and other economic indicators and performance of sectors in the same period of years; the government appropriate responses aimed at supporting enterprises and people affected by the pandemic were reviewed to propose further efforts to recover the economy and social life.

\section{RESEARCH RESULTS}

Decrease in economic growth and changes in social life as consequences of coronavirus outbreaks

As mentioned above, the outbreak and spread of the COVID-19 pandemic on a global scale has been heavily affecting the Vietnam's socio-economic development. Quarterly statistics show that the impact of the pandemic can be seen in all areas of life. GDP growth in the third quarter of 2020 is the lowest of the third quarters in the period 2011-2020. Figure 1 shows the decreasing change in GDP growth in the three quarters of 2019 and 2020.

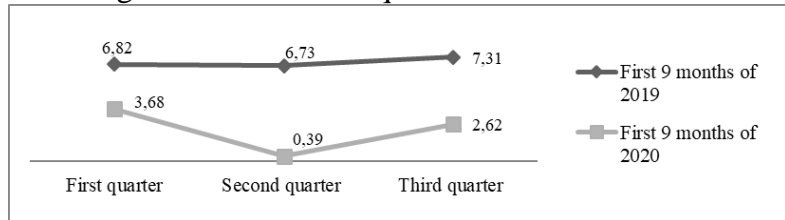

Figure 1 GDP growth in the first 9 months of 2019 and first 9 months of 2020 , in \%;

Source: GSO [8]; [9]

There were slight changes in the economic structure in nine months of 2020. The agriculture, forestry and fishery sector contributed $14.05 \%$; industry and construction accounted for $33.16 \%$; the service sector comprised $42.73 \%$; product taxes fewer subsidies on production was $10.06 \%$. The corresponding structure of the same period in 2019 was $13.21 \%, 33.97 \%, 42.75 \%$ and $10.07 \%$ respectively [9].

The Covid-19 outbreak has interrupted imports from China and other supply hubs into Vietnam, and as a result, many Vietnam's enterprises are suffered. Generally, in nine months of 2020, the whole country had nearly 99 thousand newly registered enterprises. However, nearly 78.3 thousands enterprises temporarily ceased, completed or awaited dissolution [9]. The causes and levels of difficulty facing businesses are presented in the Figure 2. In the 
whole country, over $83 \%$ of the total number of enterprises has been affected by the pandemic at different levels that leads to a temporary increase in unemployment and underemployment rate up to $5.17 \%$.

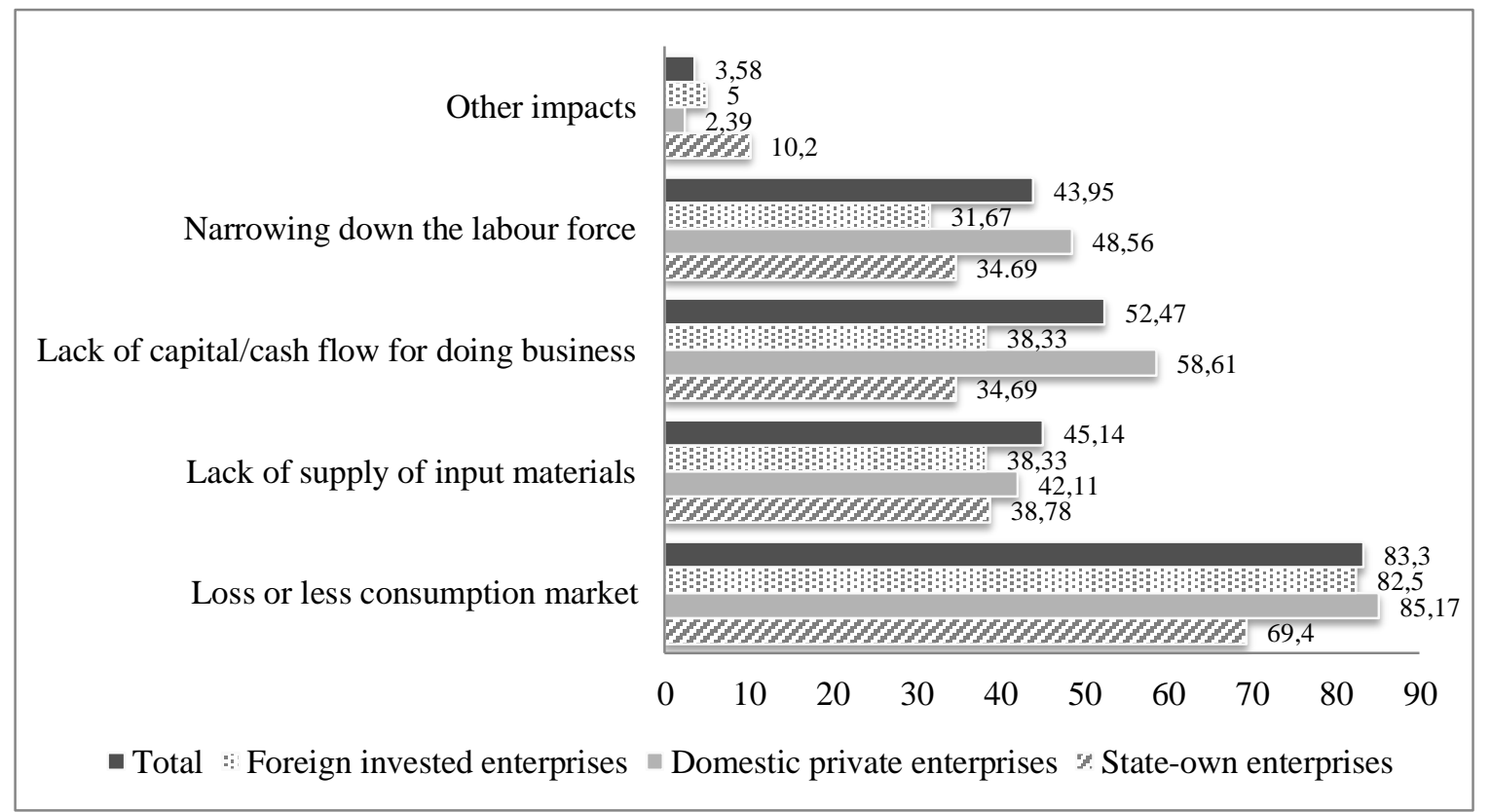

Figure 2 Impacts on enterprises caused by COVID-19 pandemic by owners as of April, 2020, in \%;

Source: Vietnam chamber of commerce and industry [10]

The Ministry of Labor, Invalids and Social Affairs (MOLISA) in September 2020 reported to the National Assembly that about one million people have lost jobs and
17 million others saw lower incomes due to the Covid-19 pandemic [11].

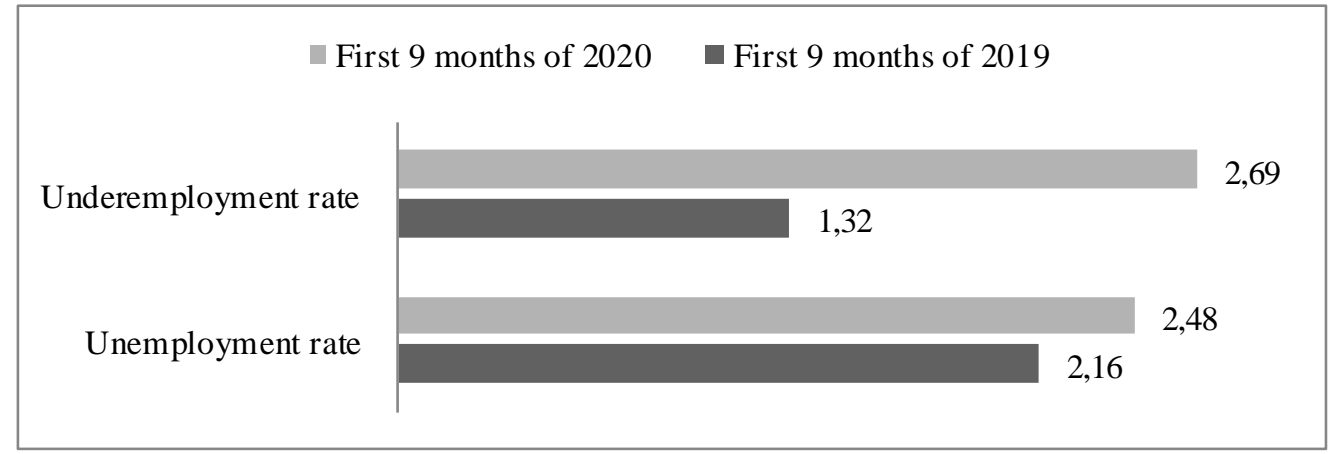

Figure 3 Unemployment and underemployment rate of laborers at working age in the first 9 months of 2019 and first 9 months of 2020, in \%; source: GSO [8],[9].

Despite complicated situation in the world and the interruption of international trade due to the pandemic, Vietnam's exports have been growing positively. Total import-export turnover in the first nine months of 2020 is estimated at US \$ 388.73 billion. 


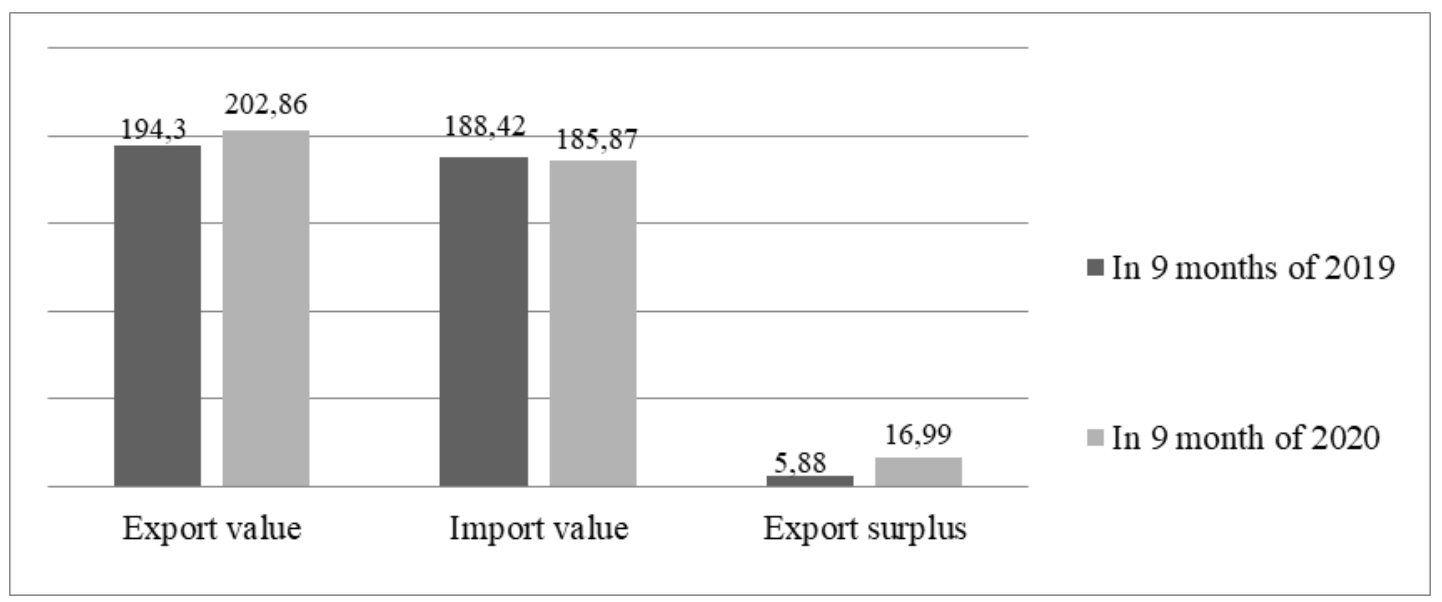

Figure 4 Export and import turnover in the first 9 months of 2020 and 9 months of 2019, US \$ billion Source: Vietnam Customs [12]

Was estimated to have an, but it the manufacturers do not satisfy with positive trade balance of goods in nine months (16.99 billion USD of export surplus), so as it warns the difficulty of importing the necessary technology, machinery and raw materials to upgrade or expand production.

Market and SC disruption

The COVID -19 pandemic outbreak cause a strong impact on the global markets such as financial, labor and consumer market, etc., which was outlined above. Our attention focuses on the volatility in the markets, including declining demand in the consumer market and the SC disruption. The outcome of a slowdown in manufacturing is known as supply shock. Disruption to a SCs caused by closing down a production site can have a domino effect that reduce the output of other companies, which in turn could impact more companies. Since production process was the most common site of serious disruption, and most likely to interfere with other disturbances which spread multidirectional along SCs [13]. Moreover, there are specific interdependencies between companies that can cause the spread of adverse effects along the SC [14].

Table 2 International visitors to Vietnam in 1st, 2nd and 3rd quarter of 220 in comparison with the same period of 2019, arrivals

\begin{tabular}{|c|c|c|c|c|c|c|}
\hline & \multirow{2}{*}{$\begin{array}{c}\text { Performance } \\
1 \text { st quarter } \\
\text { of } 2020\end{array}$} & \multirow{2}{*}{$\begin{array}{c}\text { Performance } \\
\text { 2nd quarter } \\
\text { of } 2020\end{array}$} & \multirow{2}{*}{$\begin{array}{c}\text { Estimate } \\
\text { 3rd quarter } \\
\text { of } 2020\end{array}$} & \multicolumn{3}{|c|}{ Compared to same period of 2020} \\
\hline & & & & $\begin{array}{c}\text { 1st quarter } \\
\text { of } 2020\end{array}$ & $\begin{array}{c}2 \mathrm{nd} \\
\text { of } 2020\end{array}$ & $\begin{array}{c}3 \text { rd quarter } \\
\text { of } 2020\end{array}$ \\
\hline TOTAL & 3686779 & 57697 & 44010 & 81.9 & 1.4 & 1.0 \\
\hline \multicolumn{7}{|c|}{ By citizenship and geographical territory } \\
\hline Asia & 2674367 & 55281 & 40548 & 78.9 & 1.7 & 1.1 \\
\hline Of which from China & 871819 & 47645 & 18367 & 68.1 & 4.0 & 1.2 \\
\hline America & 234050 & 327 & 794 & 79.8 & 0.1 & 0.4 \\
\hline Of which from The USA & 172706 & 81 & 426 & 78.6 & 0.0 & 0.2 \\
\hline Europe & 664251 & 1827 & 2257 & 96.9 & 0.4 & 0.5 \\
\hline Of which from Russia & 244966 & 720 & 267 & 113.6 & 0.5 & 0.2 \\
\hline Oceania & 102181 & 112 & 258 & 85.6 & 0.1 & 0.2 \\
\hline Africa & 11930 & 150 & 153 & 102.0 & 1.4 & 1.3 \\
\hline
\end{tabular}

Source: compiled from GSO statistics [9].

Social distancing, immigration restriction and other preventive measures are applied in many countries around the world, including Vietnam, lead to an unprecedented decrease in the number of international visitors to Vietnam by 3.5 times compared to the same period in 2019 (12.9 million arrivals). As a result of this decline, a series of hotels, restaurants were bankrupted or temporarily closed, and hundreds of thousands workers were unemployed or underemployed.

The VTGI's tangible outstanding feature is sourcing overseas. Practically, sourcing overseas refers to buying materials, products or services from manufacturers or suppliers that are located outside the home country. As global sourcing, it can offer advantages, including: lower overall production costs; spillover effects of world-class 
technologies from developed countries; easy access to new researches, designs or specialized knowledge for importers; ability to purchase higher quality input materials that may not be produced in the home country and a wide variety of potential suppliers to choose from; easy access to the world market through working experiences in marketing and customers [15]. But disadvantages of sourcing overseas are typically more complicated than purchasing supplies domestically and can put the production at risk of disruption due to the SC interruption for any reason.

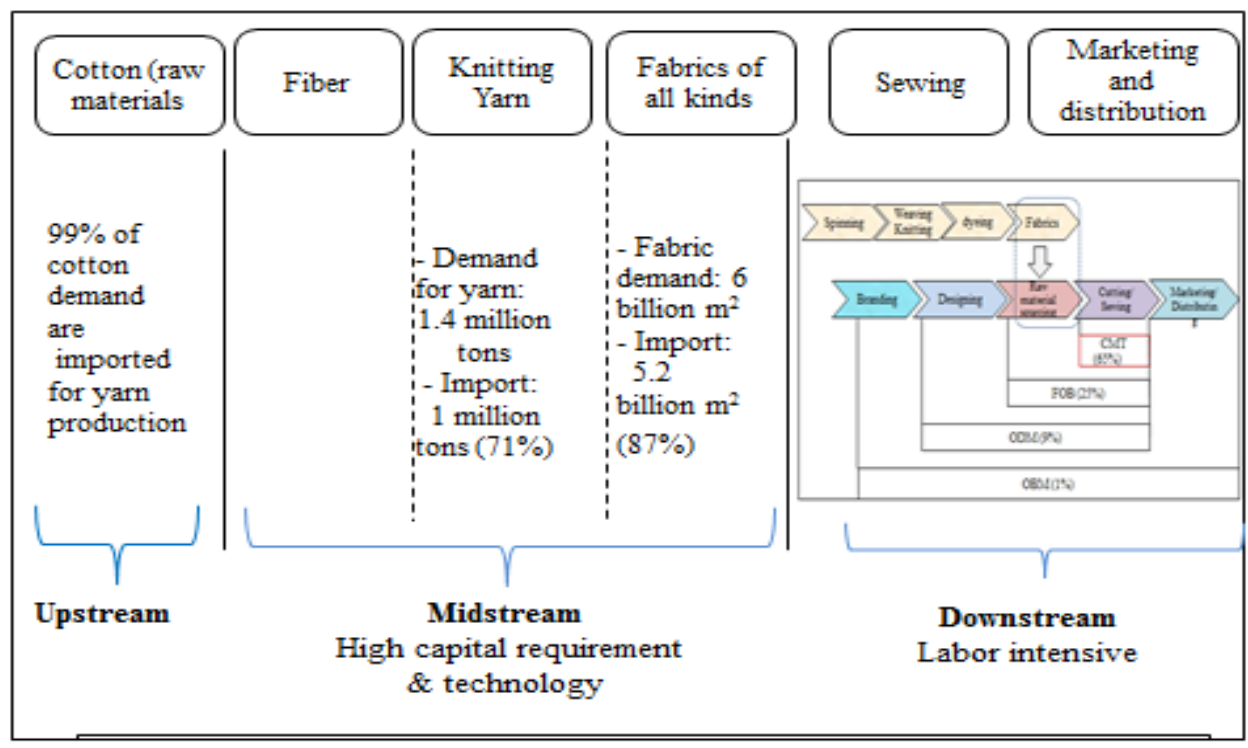

Figure 5 VTDI's value chain; source: Military Bank Securities [17].

Although VTGI had export turnover of US\$ 39.0 billion in 2019, ranking 3rd in the world after China and India in exporting goods, it relies exclusively on imports of raw materials and machinery. FPT Securities analysis showed that in 2015 sewing machines were mainly imported from
China (58\%), Japan (22\%), Chinese Taiwan (6\%), and the rest from other countries (14\%) [16]. VTGI's high dependency on global sourcing presented in Figure 5 clearly exposes its weaknesses and vulnerabilities to SC fluctuations and unpredictable changes from the GSC.

\section{Table 3 VTGI's export and import goods in the first half of 2019 and the first half of 2020}

\begin{tabular}{|c|c|c|c|c|}
\hline & \multirow{2}{*}{$\begin{array}{l}\text { Total of the first } 6 \\
\text { months of } 2019 \\
\text { (US\$ bn.) }\end{array}$} & \multicolumn{2}{|c|}{ First 6 months of 2020} \\
\hline \multicolumn{2}{|r|}{ Category } & & Total & Change to the \\
\hline \multirow{5}{*}{ 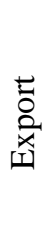 } & Fibers and yarn of all kinds & 2.03 & 1.61 & $-20,70$ \\
\hline & Clothings & 15.11 & 13.18 & -12.70 \\
\hline & Curtain and other technical fabrics & 0.31 & 0.19 & -35.70 \\
\hline & $\begin{array}{l}\text { Accessories for textile and leather } \\
\text { manufacturing }\end{array}$ & $* 0.96$ & $* 0.80$ & -16.90 \\
\hline & Total exports & 18.41 & 15.78 & -14.30 \\
\hline \multirow{5}{*}{ 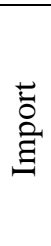 } & Total imports & 11.19 & 10.25 & -8.40 \\
\hline & Fibers and yarn of all kinds & 1.21 & 0.96 & -20.6 \\
\hline & Cotton & 1.49 & 1.26 & -15.40 \\
\hline & Fabrics of all kinds & 5.56 & 5.52 & -115.9 \\
\hline & $\begin{array}{l}\text { Accessories for textile and leather } \\
\text { manufacturing }\end{array}$ & $* 2.93$ & $* 2.51$ & -14.3 \\
\hline
\end{tabular}

Source: compiled by authors from Vietnam Customs' statistics data [12].

(*) accessories import and export of both textile and leather manufacturing are summed together in one sub-category in customs statistics 
Since first quarter of 2020, supply suspension in China has resulted in a raw material shortage in Vietnam. Meanwhile, a declining demands from the US and European markets have led to order cancellations as well as revenue and job losses for Vietnamese textile and garment manufacturers. Generally, in the first six months of 2020, VTGI had a negative growth in exports and imports by all commodities compared to the same period last year as shown in the Table 3. VTGI's export in the last six months of the 2020 is predicted to reduce by $14-18 \%$ over the same period, bringing the total export turnover in 2020 to about US\$ 32.75 billion, down about 16\% compared to 2019 [18].

Government response

To support companies that are struggling by coronavirus epidemic, the government has approved a credit package worth VND 250 trillion (US\$ 10.86 billion) and a financial stimulus package of VND 30 trillion (US\$ 1.3 billion) [19]. Various dynamic measures to directly and indirectly support businesses were also proposed as follows: (a) applying tax relief measures include extended due dates for taxpayers to pay value added tax (VAT), corporate income tax (CIT), individual (personal) income tax, and the amounts owed for land rental, including 30\% CIT reduction, extend the timeline (up to 5 months) for VAT, land rental, personal income tax; (b) Central Bank has reduced policy rates by $0.25-1$ percentage point, and several commercial banks have already lowered interest rates for businesses affected by pandemic; (c) simplifying of customs procedures, especially for goods on the List of goods exempt from import tax for epidemic prevention and control; (d) suspending social insurance fee; (e) encouraging textile and garment enterprises disrupted production to produce medical protective clothing.

To support people directly affected by the COVID-19 epidemic, social security package of up to VND 62 trillion (nearly US $\$ 2.66$ billion) was approved by the government [20]. Timely government solutions contribute to alleviating difficulties for pandemic-affected businesses and people.

New challenges and opportunities

The COVID-19 pandemic not only cause enormous challenges to the economy and people's well-being, exposed the weaknesses and vulnerabilities of the country's economic development, but also creates various opportunities for some socio-economic sectors. Online education, e-banking and e-commerce are the sectors which have reached unexpected success during the pandemic. At the beginning of the pandemic outbreak, the Ministry of Education and Training (MOET) on March 26, 2020 timely issued Instruction for teaching via internet and on TV channels during the time students are absent from schools and Regulations on ensuring the quality of teaching, checking and assessing learning results in 20192020 school year.

Digital banking and e-payment platforms have also grown. National Payment Services (NAPAS) reported that during the COVID-19 pandemic Mobile Banking, Internet Banking applications of 45 commercial banks are used through NAPAS with an average of nearly 2.8 million transactions per day [21]; a survey conducted by the Vietnam E-commerce Association (VECOM) in cooperation with a Global Measurement and Data Analytics Company (Nielsen) at the end of April 2020 showed that among businesses participated in the survey, revenue of $57 \%$ of surveyed businesses increased by less than $30 \%$, and $24 \%$ of surveyed businesses had a revenue increase of over $51 \%$ compared to the same period of 2019 [22] .VECOM predicted that the growth rate of over $30 \%$ will continue in 2020 and Vietnam's e-commerce value will exceed US\$ 15 billion compared to US\$ 11.5 billion in 2019.

Recent trends and changes in companies' production relocation and back-shoring behavior against the background of the global economic crisis were noticed [23]. The pandemic only has accelerated this process. There is a fact that Japan, the United States and developed countries tend to move production from China to home or other territories, including Vietnam and ASEAN countries. This trend provides an opportunity for Vietnam to increase cooperation with developed countries to create great chances in reshaping SCs to reduce dependency on China and some traditional markets.

In April 2020 Japan has earmarked $¥ 243.5$ billion (US\$ 2.2 billion) of its record economic support package to help manufacturers shift production out of China as the coronavirus pandemic disrupts SCs between the major trading partners [24]. In July 2020, Japan's Ministry of Economy, Trade and Industry unveiled the first group of 87 Japanese companies to subsidize for shifting manufacturing from China to Southeast Asia and Japan, of which 57 projects will head to Japan, 15 companies select Vietnam as destination [25].

\section{DISCUSSION}

SC disruption, demand reduction in both domestic and global markets put pressure on many businesses to stop operations and lay off workers [26]. Currently, there is no exact prediction about both the time frame and the effects of COVID-19, but its consequences will continue to be felt even after pandemic spread. Thus, the resilience of the production and service sectors in particular and the economy in general will have to last for many years. Apparently, the reliance of inputs and outputs on Chinese and US markets depicts the important role of specific partners that sometimes seem to be difficult to replace. In this case, certain storage of raw materials should be taken into account, avoiding production interruption caused by SC disruptions that can occur for many reasons, and bank preferential credit packages and simplified access to these loans are essential as the majority of Vietnam's enterprises are small and medium-sized ones with no collateral.

The market and SC disruption, caused by pandemic put the need to reshape SC and sourcing strategy. Therefore, in further, Vietnam's macroeconomic policies should focus on:

a) Continuing anti-epidemic measures; herewith, the government should continue to have policy proposals 
aimed to help affected businesses and people stabilize their production and lives;

b) Focusing on development of related and supporting industries (SIs), considering this as an import substitution strategy and a key to achieve the goals mentioned in the National Supporting Industry Development Program for the period of 2016-2025 that will result in domestic sourcing so as more domestic suppliers will appear, and the issue of reshaping the SC would be facilitated.

c) Emphasizing and encouraging domestic demand-led growth along with the export-led growth model, and it should be taken seriously because of the fact that the conditions for supporting export growth have been exhausted for developing countries due to the impact of the fluctuations [28]. Firstly, domestic demand-led growth encourages SI development and import substitution; secondly, it covers the increasing needs of a domestic market of 100 million people.

To confirm the importance of domestic demand-led growth, we evaluate the need to diversify activities in VTGI and Vietnam's tourism and hospitality. Due to extent of dependence on overseas sourcing and subcontracts with foreign intermediaries, most of the VTGI's enterprises restrict at CMT production mode, the lowest value added production stage, in the form of outsourcing for foreign brands that accounts for $65 \%$ of the VTGI's total production volume; of the rest FOB is $25 \%$, ODM and OBM comprise only $10 \%$ (Figure 5). That is, gradually shifting production from outsourcing (CMT) to higher profitable modes, orienting towards the demandled growth model, developing own brands should be mentioned in the VTGI's development strategy.

Vietnam's tourism and hospitality services should have to diversify the business, focusing on domestic tourism demand and upgrading tourism products for Vietnamese travellers in the long term because of improving people's living standards. This diversification is necessary to resuscitate tourism while the COVID-19 pandemic and related travel restrictions around the world still remain.

Avoiding business disruption, reshaping SC is an actual requirement nowadays. This means raising the business owner's awareness of reshaping their own SCs and promoting innovation activities, enhancing digital transformation for reaching sustainability goals and building resilient business. The enterprise SC reshaping should include restructuring and optimizing internal SCs and diversifying external SCs.

\section{CONCLUSION}

The impact of the COVID - 19 pandemic, as a whole, causes losses and disruption in socio-economic development and well-being. To recover economic activities and ensure people's daily life, a variety of abovedescribed measures have been announced by the Vietnamese government, including rescue packages for enterprises and financial social assistance for the epidemic-affected people, unemployment benefit allowance and household relief. The pandemic poses challenges, exposes shortcomings in production systems and social management, but also created opportunities for all. Vietnam needs to take advantage of the opportunities as a platform to further development. At macro level, Vietnam's government should have to clearly identify and assess the situation, and look for new strengths and appropriate development policies aimed to prevent and control the pandemic, overcome the crisis and promote socio-economic development in the future.

\section{REFERENCES}

[1] Daily news of epidemic situation, Ministry of Health, Electronic resource.

[2] IMF, April 2020: The Great Lockdown, World Economic Outlook Reports, April 2020, Electronic resource.

[3] D. J. Lynch, IMF says global economic collapse caused by coronavirus will be even worse than feared, The Washington Post, June 25, 2020, Electronic resource.

[4] I. J Chen, A. Paulraj, Towards a theory of supply chain management: the constructs and measurements. Journal of Operations Management, 22(2), (2004), pp. 119-150. DOI:

https://doi.org/10.1016/j.jom.2003.12.007

[5] S. Chopra, P. Meindl, Supply chain management: strategy, planning, and operation. 3rd edition. Upper Saddle River: Pearson Prentice Hall, 2007.

[6] I.V.Kozlenkova, G. Tomas, M.Hultb, D.J.Lund, J. Menad, P. Kekec, The Role of Marketing Channels in Supply Chain Management. Journal of Retailing, vol. 91 (4), (2015), pp. 586-609. DOI:

https://doi.org/10.1016/j.jretai.2015.03.003

[7] ASEAN Secretariat, 'Economic Impact of COVID19 Outbreak on ASEAN', ASEAN Policy Brief, April 2020, Electronic resource.

[8] GSO, Vietnam, Social and economic situation in the 3 rd quarter and 9 months of 2019, Electronic resource.

[9] GSO, Vietnam, Social and economic situation in the 3rd quarter and 9 months of 2020, Electronic resource.

[10] VCCI, Rapid Assessment Report: The impact of COVID-19 pandemic on labour and employment in enterprises in Vietnam, Hanoi, April, 2020, Electronic resource. 
[11] A. Kiet, T.Truc. Millions of jobs affected by Covid-19, September, 9, 2020, Electronic resource.

[12] Vietnam Customs, Periodic customs statistics, Electronic resource.

[13] G. Wieteska, The domino effect - disruptions in supply chains. Scientific Journal of Logistics, 14 (4) (2018), pp. 492-506, DOI:

http://dx.doi.org/10.17270/J.LOG.2018.302

[14] G. Svensson, A conceptual framework for the analysis of vulnerability in supply chains, International Journal of Physical Distribution \& Logistics Management, 30 (9), 2004, pp. 731-750, DOI: http://dx.doi.org/10.1108/09600030010351444

[15] L. Quintens, P. Pauwels, P. Matthyssens, Global purchasing: State of the art and research directions, Journal of Purchasing \& Supply Management 12, 2006, pp. 170-181, DOI: 10.1016/j.pursup.2006.10.006

[16] FPT Securities, Vietnam Textile and Garment Industry, fpts, (2017), Electronic resource.

[17] Q. H. Nguyen, (Vietnam Textile and Garment Industry, Military Bank Securities, MBS, 2019, Electronic resource.

[18] D. Anh, H. Hanh, Forecast of textile market situation in the last 6 months of 2020. Vinatex, July, 22, 2020, Electronic resource.

[19] Ngoc Mai, 'Vietnam Announces USUS\$ 12billion Stimulus Package for Enterprises', Hanoi times Magazine online, March, 06, 2020, Electronic resource.

[20] V. Nhu, Gov't releases package to support coronavirus-hit groups, online Newspaper of Vietnam Government, April, 10, 2020, Electronic resource.

[21] NAPA 'Digital banking and electronic payments suggestions from the COVID -19 crisis', NAPAS' eportal, May, 22, 2020, Electronic resource.

[22] VECOM, Vietnam: E-commerce will Speed Up after the COVID-19 Pandemic, VECOM's report, Electronic resource.
[23] S. Kinkel, Trends in production relocation and backshoring activities: Changing patterns in the course of the global economic crisis, International Journal of Operations \& Production Management, 32(6), May 2012. DOI:

http://dx.doi.org/10.1108/01443571211230934

[24] I. Reynolds, E. Urabe, Japan to Fund Firms to Shift Production Out of China, Bloomberg, April 8, 2020, Electronic resource.

[26] Nikkei Staff Writers, Japan reveals 87 projects eligible for 'China exit' subsidies, Nikkei Asia, Electronic resource.

[27] S.Pritesh, COVID-19 and the Effects on Supply Chains in Vietnam. Vietnam Briefing, April, 10, 2020), Electronic resource.

[28] T. I. Palley, The End of Export-led Growth: Implications for Emerging Markets and the Global Economy. Shanghai Briefing Paper Mar. 2011, No. 6, Electronic resource. 